Canadian

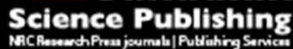

Canadian Geotechnical Journal Revue canadienne de géotechnique

\title{
Numerical investigation of the earth pressure coefficient along the central line of backfilled stopes
}

\begin{tabular}{|r|l|}
\hline Journal: & Canadian Geotechnical Journal \\
\hline Manuscript ID & cgj-2016-0165.R3 \\
\hline Manuscript Type: & Note \\
\hline Date Submitted by the Author: & 02-Sep-2016 \\
\hline Keyword: List of Authors: & $\begin{array}{l}\text { Sobhi, Mohamed Amine; École Polytechnique de Montréal, Department of } \\
\text { Civil, Geological and Mining Engineering } \\
\text { Li, Li; École Polytechnique de Montréal, Department of Civil, Geological and } \\
\text { Mining Engineering } \\
\text { Aubertin, Michel; École Polytechnique de Montréal, }\end{array}$ \\
\hline &
\end{tabular}




\title{
Numerical investigation of the earth pressure coefficient along the central line of backfilled stopes
}

\author{
Mohamed Amine Sobhi, Li Li*, and Michel Aubertin
}

Research Institute on Mines and the Environment Department of Civil, Geological and Mining Engineering École Polytechnique de Montréal C.P. 6079, Succursale Centre-Ville, Montréal, PQ, H3C 3A7 Canada

*Corresponding author. Tel: 1-514-340-4711 \#2408; fax: 1-514-340-4477; e-mail: 1i.li@polymtl.ca

Technical note (cgj-2016-0165R3) resubmitted to Canadian Geotechnical Journal

Submitted: March 2015

Evaluation received: May 2015

Revised version submitted: March 2016

Second evaluation received: May 2016 Updated (Revised) version submitted: June 2016

Third evaluation received: July 2016 Re-updated version submitted: August 2016 Forth evaluation received: August 2016 Fifth version submitted: September 2016 


\title{
Numerical investigation of the earth pressure coefficient along the central line of backfilled stopes
}

\author{
Mohamed Amine Sobhi, Li Li*, and Michel Aubertin
}

\begin{abstract}
The earth pressure coefficient $K$, defined as the horizontal to vertical normal (effective) stresses ratio $\left(\sigma_{\mathrm{h}} / \sigma_{\mathrm{v}}\right)$, is a key parameter in analytical solutions for estimating the stresses in backfilled stopes. In the case of vertical stopes, the value of $K$ has sometimes been defined using the at-rest earth pressure coefficient $K_{0}$, while others have applied Rankine's active earth pressure coefficient $K_{\mathrm{a}}$. To help clarify this confusing situation, which can lead to significantly different results, the origin and nature of the at-rest and Rankine's active coefficients are first briefly recalled. The stress state in backfilled stopes is then investigated using numerical simulations. The results indicate that the value of $K$ can be close to $K_{\mathrm{a}}$ for cohesionless backfills along the vertical central line (CL) of vertical stopes, due to sequential placement and partial yielding of the backfill. For inclined stopes, simulations show that the ratio between the minor and major principal stresses $\left(\sigma_{3} / \sigma_{1}\right)$ along the $\mathrm{CL}$ in the backfill, which differs from $\sigma_{\mathrm{h}} / \sigma_{\mathrm{v}}$, can also be close to $K_{\mathrm{a}}$. A simple expression is shown to represent well the horizontal to vertical stresses ratio $\sigma_{\mathrm{h}} / \sigma_{\mathrm{v}}(=K)$ along the central line of such inclined stopes. A discussion follows on the effects of backfill properties and simulation approach.
\end{abstract}

Key-words: Mines, Backfill, Earth pressure coefficient, Numerical modeling, Rankine.

"Corresponding author. Tel: 1-514-340-4711 \#2408; fax: 1-514-340-4477; e-mail: li.li@polymtl.ca 
59 Résumé: Le coefficient de poussée des terres $K$, défini comme le rapport entre les contraintes 60 normales (effectives) horizontale et verticale $\left(\sigma_{\mathrm{h}} / \sigma_{\mathrm{v}}\right)$, est un paramètre clé utilisé dans les 61 solutions analytiques pour estimer les contraintes dans des chantiers remblayés. Pour les 62 chantiers verticaux, la valeur de $K$ est occasionnellement définie selon le coefficient de 63 poussée des terres au repos $K_{0}$, alors que d'autres ont plutôt utilisé le coefficient de poussée 64 des terres actif de Rankine $K_{\mathrm{a}}$. Pour clarifier cette situation ambigüe, qui peut conduire à des 65 résultats assez différents, l'origine et la nature des coefficients au repos et actif sont d'abord 66 brièvement rappelés. L'état des contraintes dans des chantiers remblayés est évalué à partir de 67 simulations numériques. Les résultats indiquent que cette valeur peut être proche du coefficient $K_{\mathrm{a}}$ pour les remblais sans cohésion le long de la ligne de centre dans les chantiers verticaux, en raison de la mise en place progressive et de l'atteinte d'un état de plasticité partiel du remblai. Pour les chantiers remblayés inclinés, les résultats montrent que le rapport entre les contraintes principales mineure et majeure $\left(\sigma_{3} / \sigma_{1}\right)$ le long de la ligne de centre dans le remblai, qui diffère du rapport $\sigma_{\mathrm{h}} / \sigma_{\mathrm{v}}$, peut aussi être proche du coefficient de poussée des terres actif de Rankine. Une expression simple peut être utilisée pour représenter le rapport entre les contraintes horizontale et verticale $\sigma_{\mathrm{h}} / \sigma_{\mathrm{v}}(=K)$ le long de la ligne centrale des chantiers remblayés inclinés. Une discussion suit en lien avec l'effet des propriétés du remblai et de l'approche pour mener les simulations.

Mots-clés: Mines, Remblai, Coefficient de poussée des terres, Modélisation numérique, Rankine. 


\section{Introduction}

Stope backfilling is widely used in Canada and elsewhere, in part because it helps reduce the environmental impact of mining operations by returning mining wastes underground (Bussière 2007; Benzaazoua et al. 2008). But the main purposes of mine backfill are to improve ground stability, provide a safer work space, reduce ore dilution, and help control the air flow (Hassani and Archibald 1998; Darling 2011; Hambley 2011).

A key issue for the design of backfilled stopes is the determination of the stresses in the backfill. A few analytical expressions have been proposed to this effect. These are mostly based on the approach adopted by Marston (1930), who made use of the Janssen (1895) arching theory to calculate the vertical load on buried conduits in backfilled trenches. The corresponding vertical stress can be expressed as follows:

$$
\sigma_{\mathrm{v}}=\frac{\gamma B}{2 K \tan \delta}\left[1-\exp \left(-\frac{2 K \tan \delta}{B} h\right)\right]
$$

where $B(\mathrm{~m})$ is the width of the opening, $h(\mathrm{~m})$ is the depth in the fill, $\gamma\left(\mathrm{kN} / \mathrm{m}^{3}\right)$ is its unit weight, $\delta\left(^{\circ}\right)$ is the friction angle along the interfaces between the backfill and wall material, and $K(-)$ is the earth pressure coefficient which is defined as the ratio between the horizontal $\left(\sigma_{\mathrm{h}}\right)$ and vertical $\left(\sigma_{\mathrm{v}}\right)$ normal effective stresses $(\mathrm{kPa})$. For narrow openings, eq. (1) typically leads to vertical stresses that are much smaller than the overburden stresses, due to a load transfer from the soft backfill to the stiff walls, thus producing an arching effect (e.g., Handy and Spangler 2007).

Equation (1) has been applied to vertical mine backfilled stopes using $\delta=\phi$, where $\phi\left(^{\circ}\right)$ is the internal friction angle of the (cohesionless) backfill (Aubertin et al. 2003). This assumption implies that the strength along the fill-wall interfaces is controlled by the backfill strength, hence considering that yielding occurs in the fill material rather than directly along the walls (due to their very rough surface). 
This type of formulation has also been extended for inclined backfilled stopes (e.g., Caceres 2005; Ting et al. 2011, 2014; Jahanbakhshzadeh 2016).

The effects of cohesion and of a three-dimensional geometry (Li et al. 2005), pore water pressures ( $\mathrm{Li}$ and Aubertin 2009a, 2009b), and non-uniform stress distribution across the stope width (Li and Aubertin 2008, 2010) have also been introduced in modified expressions based on eq. (1). Other 3D formulations, also related to eq. (1), have been proposed by Van Horn (1964), Winch (1999), and Pirapakaran and Sivakugan (2007a).

All these solutions (and others) use the lateral earth pressure coefficient, $K$, as a state parameter to evaluate the stresses in backfilled openings. The value of $K$ can significantly affect the calculated stresses within the backfill (Li et al. 2003). There is however an uncertainty regarding how $K$ should be defined for backfilled stopes. This issue is addressed in the following, considering first the basic concept behind $K$ and then analyzing the stresses along the central line of stopes using results from numerical simulations. Although the calculations presented here neglect the effect of pore water pressure, the same concept can easily be extended to cases where the backfill contains water that generates positive pressures (e.g., Li and Aubertin 2009a, 2009b).

\section{Earth pressure coefficient $K$}

The well-known earth pressure coefficient concept was originally developed in soil mechanics to analyse the stress state in natural deposits and the pressure on retaining walls (e.g., Coulomb 1776; Rankine 1857; Jaky 1944; Lambe and Whitman 1979; Terzaghi et al. 1996). The corresponding earth pressure coefficient $K$ is usually defined as the ratio between the horizontal $\left(\sigma_{\mathrm{h}}\right)$ and vertical $\left(\sigma_{\mathrm{v}}\right)$ normal stresses, which are also the minor $\left(\sigma_{3}\right)$ and major $\left(\sigma_{1}\right)$ principal stresses in a normally consolidated soil deposit with a horizontal surface (i.e. $\sigma_{\mathrm{h}} / \sigma_{\mathrm{v}}=$ $\left.\sigma_{3} / \sigma_{1}\right)$ 
When a soil in a semi-infinite space is under static equilibrium, the vertical (principal)

$$
\sigma_{\mathrm{v}}=\not h
$$

The horizontal stress is proportional to the vertical stress, so one can write:

$$
\sigma_{\mathrm{h}}=K \sigma_{\mathrm{v}}
$$

Equations (2) and (3) constitute the traditional overburden solution for estimating the stresses in a soil deposit in geotechnical engineering. Parameter $K$ is usually called the (lateral) earth pressure coefficient, or a close variant of this term (e.g., Bowles 1992; CGS 2006; McCarthy 2007; Holtz et al. 2011).

For a normally consolidated soil at-rest (i.e. where vertical loads do not induce horizontal strain), $K=K_{0}$. Although the value of $K_{0}$ can theoretically be defined from Poisson's ratio $\mu$ (e.g., Aysen 2005; Blight 2010), geotechnical engineers generally use the following semiempirical expression proposed by Jaky (1944), which relates the at-rest earth pressure coefficient to the (effective) internal friction angle $(\phi)$ of the soil:

$$
K_{0}=1-\sin \phi
$$

A number of researchers have shown that Jaky's expression (eq. (4)) represents well the measured horizontal to vertical stresses ratio for normally consolidated soils (e.g., AlHussaini and Townsend 1975; Ladd et al. 1977; Mesri and Hayat 1993).

When a soil (or fill) submitted to vertical loading is retained by a smooth vertical wall of limited stiffness, there will be some horizontal movement that may result in a reduction in the horizontal stress $\sigma_{\mathrm{h}}$ (compared with the $K_{0}$ condition). The Mohr circle defining the new stress state can then meet the Coulomb yield surface (e.g., McCarthy 2007; Sobhi et al. 2014). In this case, the soil is said to have reached an active state following yielding. The corresponding horizontal to vertical stresses ratio can then be defined with Rankine's active earth pressure 
153 coefficient, $K_{\mathrm{a}}$, which can be expressed as follows for a horizontal surface (e.g., CGS 2006;

154 Das 2010):

155

$$
K_{\mathrm{a}}=\frac{\sigma_{\mathrm{h}}}{\sigma_{\mathrm{v}}}=\frac{\sigma_{3}}{\sigma_{1}}=\frac{1-\sin \phi}{1+\sin \phi}=\tan ^{2}\left(45^{\circ}-\frac{\phi}{2}\right)
$$

Equations (4) and (5) have both been used to calculate the stresses in backfilled openings, including mine stopes. It is however unclear which one (if any) of these two expressions should be applied in such cases.

\section{Assessing the value of $K$ for mine backfilled stopes}

As stated above, analytical solutions developed for estimating the stresses in backfill placed in mine stopes are usually based on Marston's approach (eq. (1)). For vertical backfilled stopes, some numerical calculations and indirect measurements have indicated that Rankine's active earth pressure coefficient (eq. (5)) is close to the horizontal to vertical stresses ratio along the central line (e.g., Li et al. 2003, 2005; Li and Aubertin 2009a, 2009b; Ting et al. 2012). Using the value of coefficient $K_{\mathrm{a}}$ also agrees with Marston's (1930) results for the loads on conduits in backfilled trenches (see also McCarthy 1988; Handy and Spangler 2007).

An illustration of how the value of $K$ may influence the stress state in a backfilled opening is shown in Fig. 1, using experimental results taken from Pirapakaran and Sivakugan (2007b) and the 3D arching solution of Li et al. (2005), which is a direct extension of eq. (1). Both the at-rest $K_{0}$ (eq. (1)) and Rankine's active $K_{\mathrm{a}}$ (eq. (5)) coefficients have been used to calculate the vertical stresses shown in the figure. As can be seen, the experimental results indicate that there is a pronounced arching effect, with the measured vertical stresses being much smaller than the overburden pressures (especially at depth). It can also be observed that a better agreement between the experimental measurements and analytical solution is obtained in this 
177 experimental and analytical results presented by Li et al. (2005), which showed that a good 178 agreement can be obtained for $K=K_{\mathrm{a}}$.

179 Nonetheless, many authors working on the behavior of fills in bins and in trenches or 180 behind retaining walls have been using $K=K_{0}$ in analytical solutions to define the stresses 181 (e.g., Take and Valsangkar 2001; Blight 2006). This assumption was also adopted for 182 backfilled stopes (e.g., Winch 1999; Pirapakaran and Sivakugan 2007a, 2007b; Fahey et al. 183 2009; Singh et al. 2010, 2011; Ting et al. 2011). In such cases, the use of $K=K_{0}$ may appear 184 to be justified because the walls are very stiff, so the horizontal displacements (and strains) in 185 the backfill should be very small (or nil), hence leading to an at-rest state. This assumption could however be questioned because the high compressibility of the fill, its sequential placement, and the presence of the rock walls can lead to some stress rotation and differential lateral strains under vertical loading, as indicated for instance by numerical simulations performed by Falaknaz (2014; see also Falaknaz et al. 2015b). In the following, additional analyses are performed using numerical simulations to assess the earth pressure coefficient along the central line (CL) of backfilled stopes with parallel vertical and inclined walls.

\section{Numerical simulations}

Numerical simulations have been performed to assess the stress ratio in backfilled stopes, considering the effect of stope geometry and backfill properties. The focus is placed here on the earth pressure coefficient $K\left(=\sigma_{\mathrm{h}} / \sigma_{\mathrm{v}}\right)$ along the central line of the stopes, where the effects of the shear stresses developing along the walls are minimal. The finite element software SIGMA/W (GEO-SLOPE 2010) was used to run the simulations; additional details are provided in Sobhi (2014).

Figure 2a shows a backfilled stope model, which includes a void space of $0.5 \mathrm{~m}$ above the 
202

203

204

205

206

207

208

209

210

211

212

213

214

215

216

217

218

219

220

221

222

223

224

225

226

elasto-plastic model with the Coulomb yield criterion; the rock mass is isotropic, homogenous and linear elastic. A typical stress regime for the Canadian Shield is applied, where the natural vertical in-situ stress is calculated based on the overburden weight and the horizontal natural stress is twice the vertical stress. An example of a numerical model built in SIGMA/W is shown in Fig. $2 b$.

Each numerical simulation was conducted in three steps: i) model construction to obtain a rock mass space submitted to the external and self-weight stress regime; ii) excavation of the stope and release of elastic strains in the rock mass; iii) backfilling of the stope in four layers (similarly to Li and Aubertin 2009c). There is no interface element along the rock walls in the models; this may influence the magnitude of the stresses obtained with SIGMA/W (El Mkadmi et al. 2014), but it does not significantly affect the stress ratio being assessed here (Sobhi 2014).

The reference case configuration consists of a $6 \mathrm{~m}$ wide and $45 \mathrm{~m}$ high vertical stope surrounded by the elastic rock mass characterized by $E_{\mathrm{r}}=30 \mathrm{GPa}$ (Young's modulus), $\mu_{\mathrm{r}}=$ 0.3 (Poisson's ratio) and $\gamma_{\mathrm{r}}=27 \mathrm{kN} / \mathrm{m}^{3}$ (unit weight). The stope is filled with a cohesionless backfill characterized by $E=300 \mathrm{MPa}, \mu=0.2, \gamma=18 \mathrm{kN} / \mathrm{m}^{3}, \phi=30^{\circ}$ (friction angle) and $\psi=$ $0^{\circ}$ (dilation angle, with a non-associated flow rule).

In addition to the reference case, various other simulations have been conducted with one parameter varied at a time in order to evaluate its influence on the earth pressure coefficient $K$. Details on the reference case and other simulated cases are summarized in Table 1.

\section{Numerical results}

\section{Reference case}

Figure 3 shows the vertical and horizontal stresses distribution (Fig. 3a) along the CL of the vertical stope for the reference case, together with the iso-contours of the horizontal $\sigma_{\mathrm{h}}$ (Fig. 
3b) and vertical $\sigma_{\mathrm{v}}$ (Fig. 3c) stresses obtained with SIGMA/W. From Figure 3a, it can be seen that there is a nonlinear stress increase with depth. Across the width of the stope, the horizontal (Fig. 3b) and vertical (Fig. 3c) stresses tend to decrease from the stope center to the walls. These correspond well to typical stress distribution in backfilled openings due to arching effect (Li et al. 2003; Li and Aubertin 2008, 2009c; Falaknaz 2014; Falaknaz et al. 2015a).

The earth pressure coefficient $K$ is calculated as the ratio between the horizontal and vertical stresses along the central line obtained with the code SIGMA/W. The numerical results giving the variation of coefficient $K$ with depth along the CL of the vertical backfilled stope for the reference case configuration is shown in Fig. 4. The Rankine's active coefficient $K_{\mathrm{a}}=0.33$ (Eq. (5) with $\phi=30^{\circ}$ ) and the at-rest coefficient based on Jaky's equation $K_{0}=0.5$ (Eq. (4) with $\phi=30^{\circ}$ ) are also shown on Fig. 4. It is seen that the value of $K$ obtained from the numeral simulation is close to $K_{\mathrm{a}}$ along most of the CL. However, the value of $K$ tends toward Jaky's (eq. (4)) at-rest coefficient $K_{0}$ in the upper part of the stope.

These numerical results correspond well to the tendency reported by Thompson et al. (2012), based on measurements performed at the Cayeli mine, located in the province of Rize, Turkey; these indicated that the effective stresses in the backfill in the lower central portion of a stope were close to an active state while the upper portion was near to the at-rest state.

\section{Effect of stope geometry}

Figure 5 shows the variation of $K\left(=\sigma_{\mathrm{h}} / \sigma_{\mathrm{v}}\right)$ along the CL of vertical stopes width $B$ ranging from $4 \mathrm{~m}$ to $10 \mathrm{~m}$ (Case 1, Table 1). One sees that the earth pressure coefficient remains very close to Rankine's active earth pressure coefficient $K_{\mathrm{a}}$ (eq. (5)) for all simulations. As was the case for Case 0 (Fig. 4), the simulated value of $K$ appears somewhat overestimated by Jaky's equation (eq. (4)), except near the top. 
The variation of the earth pressure coefficient $K=\sigma_{\mathrm{h}} / \sigma_{\mathrm{v}}$ along the CL of backfilled stopes with walls having various inclination angles $\alpha$ (between $90^{\circ}$ to $50^{\circ}$ ) is shown in Fig. 6 . It is seen that the value of coefficient $K$ is very sensitive to angle $\alpha$. There is a significant increase in the value of $K$ with a decrease of the wall inclination angle. This tendency agrees with the numerical simulations results of $\mathrm{Li}$ and Aubertin (2009c), who showed that the horizontal stresses are almost insensitive to the stope inclination while the vertical stresses tend to decrease when $\alpha$ decreases. The observed trend also agrees with those reported by Li et al. (2012, 2013) and Li and Aubertin (2015) for trenches with inclined walls.

This increase in the value of $K$ with a decrease of angle $\alpha$ was thus expected, but the magnitude of this effect was not necessarily anticipated.

For the stope geometry and backfill properties considered here, the earth pressure coefficient $K$ for vertical $\left(\alpha=90^{\circ}\right)$ and sub-vertical $\left(\alpha=80^{\circ}\right)$ stopes along the $\mathrm{CL}$ is well represented by the Rankine's active earth pressure. Jaky's at-rest earth pressure coefficient (eq. (4)) is less representative of the simulations results, except may be for $\alpha=60^{\circ}$ (but this agreement may be fortuitous)

The results shown in Fig. 6 furthermore indicate that the expressions presented above cannot directly be used to represent the earth pressure coefficient $K\left(=\sigma_{\mathrm{h}} / \sigma_{\mathrm{v}}\right.$, along the CL) when the wall inclination angle varies significantly from $90^{\circ}$; the difference with the value of $K_{\mathrm{a}}$ becomes particularly important for $\alpha \leq 70^{\circ}$ (for the conditions analyzed here). This aspect will be further discussed below.

Additional analysis of the numerical simulations results indicates that for stopes with inclined walls, the horizontal and vertical stresses along the CL are not principal stresses, contrarily to vertical stopes (where $\left.\sigma_{\mathrm{h}} / \sigma_{\mathrm{v}}=\sigma_{3} / \sigma_{1}\right)$.

The ratio of the principal (effective) stresses $K_{\mathrm{ps}}=\sigma_{3} / \sigma_{1}$ along the CL was evaluated for various stope inclination angles $\alpha$. As it can be seen on Fig. 7, the value of $K_{\mathrm{ps}}$ is close to 
277 Rankine's active coefficient $K_{\mathrm{a}}$, except very near the top of the backfill. This suggests that the 278 backfill may be fairly close to an active state along the CL of inclined stopes (when the latter 279 state is defined from the principal stresses).

280

281

\section{Effect of backfill properties}

282

Various characteristics of the backfill have been varied in the following simulations to assess their influence on the stress state and on the value of $K$. It is first noted that the numerical calculations have shown that there is no influence of the backfill Young's modulus on the lateral earth pressure coefficient for $E$ between $3 \mathrm{MPa}$ to $3 \mathrm{GPa}$ (results not shown here). There is however a significant effect of Poisson's ratio $\mu$ on the stress state (Li and Aubertin 2009c; Falaknaz et al. 2015b; Jahanbakhshzadeh 2016); this aspect will be discussed briefly below.

As the internal friction angle $\phi$ of the backfill (for a constant $\mu$ value) influences the stress state in stopes ( $\mathrm{Li}$ and Aubertin 2009c), it was also expected to affect the value of coefficient $K$. Figure 8 shows that the value of $K$ given by the simulations is usually fairly close to Rankine's active earth pressure coefficient (eq. (5)) for values of $\phi$ going from $10^{\circ}$ to $40^{\circ}$, particularly in the deeper part of the stope.

\section{An expression for coefficient $K$ in inclined stopes}

In the case of narrow inclined stopes, the simulations showed that the horizontal and vertical stresses along the CL are not principal stresses (because of the induced shear stresses). The results shown above have also shown that the ratio of the principal stresses $K_{\mathrm{ps}}\left(=\sigma_{3} / \sigma_{1}\right)$ is close to $K_{\mathrm{a}}$. 
The numerical results further indicated that the earth pressure coefficient $K\left(=\sigma_{\mathrm{h}} / \sigma_{\mathrm{v}}\right)$ is very sensitive to the stope walls inclination angle $\alpha$. This aspect is not taken into account in the equations presented above.

An analysis of the simulations results has shown that the following expression represents well the value of the earth pressure coefficient as a function of the stope inclination $\alpha$ and the backfill internal friction angle $\phi$ :

$$
K=K_{\alpha}=\frac{1+K_{\mathrm{a}}}{2}+\frac{1-K_{\mathrm{a}}}{2} \cos 2 \alpha
$$

where $\alpha\left(50^{\circ} \leq \alpha \leq 90^{\circ}\right)$ is the stope wall inclination angle and $K_{\mathrm{a}}$ is Rankine's active earth pressure coefficient. Equation (6) defining $K_{\alpha}\left(=\sigma_{\mathrm{h}} / \sigma_{\mathrm{v}}\right)$ is based on an expression presented by Ting et al. (2011), but which does not consider Rankine's active state (and which also includes an additional term that is a function of the friction angle along the walls; this term is not considered here).

Figure 9 shows a comparison between the value of $K_{\alpha}$ calculated with eq. (6) and the earth pressure coefficient $K\left(=\sigma_{\mathrm{h}} / \sigma_{\mathrm{v}}\right)$ obtained from the numerical simulations for different stope inclination angles, for a backfill internal friction angle of $30^{\circ}$. It is seen that a good agreement is obtained for $\alpha$ varying from $50^{\circ}$ to $90^{\circ}$.

Additional numerical simulations were performed using an internal friction angle $\phi=20^{\circ}$ and $40^{\circ}$ for the backfill (see Sobhi 2014). Again, a good agreement is obtained between the earth pressure coefficient $K_{\alpha}$ calculated with eq. (6) and those obtained from the numerical simulations along the central line.

These results thus suggest that eq. (6) can be used to determine the earth pressure coefficient $K$ along the CL of inclined stopes backfilled with cohesionless material.

\section{Discussion}


324 The numerical modeling results presented above indicate that the active earth pressure

325 coefficient $K_{\mathrm{a}}$ could be applied to assess the stresses along the CL of vertical backfilled stopes

326 with solutions based on Marston's equation (eq. (1)), except very near the top surface where

327 the backfill is closer to an at-rest state. This suggests that $K$ should also be expressed as a

328 function of the depth $h$, as shown by the recent work of Jahanbakhshzadeh (2016).

329 The results specifically show that there is an increase in the value of $K$ near the top of the 330 backfill. This could be related to the effect of backfill placement (added in layers), which 331 tends to produce vertical and horizontal stresses that can be initially much higher than the 332 overburden. Near the surface, the excess stresses in the backfill can be released in the vertical 333 direction, but these are partly locked in the horizontal direction, hence producing a higher 334 horizontal to vertical stress ratio (i.e. larger value of $K$ ).

335 As mentioned previously, the trends provided by the numerical results have also been 336 confirmed (in part) by those provided by field measurements at the Cayeli mine, located in the 337 province of Rize, Turkey (Thompson et al. 2012). Similar experimental observations, which 338 point in the same direction, have also been reported for the Goldcorp Inc.'s Red Lake Mine 339 (Hughes et al. 2010) and for laboratory tests on physical models (Fig. 1; see also Pirapakaran 340 and Sivakugan 2007b; Ting et al. 2012).

341 More laboratory work on this aspect can be needed. But, these numerical and experimental 342 results may appear to be going against intuition for backfilled stopes, as it could be expected 343 that the very stiff rock walls would produce an at-rest state $\left(K=K_{0}\right)$ in the openings (as is 344 postulated by some).

345 This apparent conundrum may be resolved, at least partially, by recalling that Rankine's 346 active state is related to yielding of the material (e.g., McCarthy 2007; Sobhi et al. 2014). A 347 movement of the confining walls is not a necessary condition to reach an active state in a 348 backfilled stope. Such active (yielding) state can also be reached as a result of other 
mechanisms, such as a variation of the deviatoric stresses in the very soft (deformable) backfill following sequential placement, which may bring the stress state close to or in contact with the yield surface (especially at depth). This is illustrated in Fig. 10, which shows that a (plastic) yielding state is reached in a large part of the backfill after complete filling of the stope (based on a simulation result with the elasto-plastic model). When the stresses in the backfill reach the (plastic) yield criterion, the stress state will be controlled by the adopted plasticity theory and the stress ratio may approach an active state in the stope.

\section{Limitations}

The results presented above illustrate how numerical simulations can be used to help with the validation and calibration of analytical solutions. Some reservations must nonetheless be expressed when reviewing the calculations presented here. One of these relates to the value of the Poisson's ratio $\mu$, which is taken as a constant here $(\mu=0.2)$. It is thus considered as being independent from the internal friction angle $\phi$ of the backfill in the simulations. However, the work of Jaky (1944) on the at-rest coefficient, and of various others since then (e.g., Holtz et al. 2011), suggests that both parameters ( $\mu$ and $\phi)$ should be related for consistency (with the elasto-plastic model), so that a unique value of $K_{0}$ would be obtained from either eq. (4) or the well-known expression $K_{0}=\mu /(1-\mu)$ when the backfill responds according to the commonly used elasto-plastic (Mohr-Coulomb) model. Work is ongoing to evaluate if testing results obtained on granular materials supports such inter-related values for $\mu$ and $\phi$. Applying the corresponding relationship between $\mu$ and $\phi$ in the simulations can influence the stress state (Falaknaz 2014; Falaknaz et al. 2015b; Jahanbakhshzadeh 2016), but the analysis presented above on the value of $K$ remains relevant.

Other limitations of this work pertain to some of the characteristics of the finite element code used for these calculations, which have been addressed by El Mkadmi et al. (2014) and 
373 Sobhi (2014). For instance, the analyses conducted by Sobhi (2014) indicate that the

374 magnitude of the stresses in the stope may depend on the number of layers used to place the

375 backfill in the modelled opening and on the conditions imposed along the rock walls (i.e.

376 presence or absence of interface or transition elements). However, these factors do not

377 influence the value of the stress ratio $\sigma_{\mathrm{h}} / \sigma_{\mathrm{v}}$ obtained from the numerical simulations. The

378 results presented here are thus representative of the conditions being evaluated to assess the 379 value of $K$.

380 Also, it should be recalled that the focus of this study was placed on the earth pressure 381 coefficient along the CL of backfilled stopes, where the principal stresses would typically act 382 along the vertical and horizontal axes (in plane strain). It is known however that the stresses 383 and earth pressure coefficients are not uniform across the width of the openings (Li and 384 Aubertin 2008, 2010). Additional work is underway to assess the value of $K$ across the width 385 and near the walls of backfilled stopes.

386 Interface elements were not included in the models used here. Recent simulations 387 performed by Liu et al. $(2016 a, 2016 b)$ tend to indicate that the introduction of interface 388 elements is usually not required when the surface of the walls are very rough (irregular), or 389 when the friction angle along the walls is close to that of the backfill; the latter condition has 390 been observed from recent laboratory tests results (e.g., Fall and Nasir 2010; Koupouli et al. 391 2016). Nonetheless, this aspect still needs some more work.

392 Finally, it should be recalled that eq. (6) was formulated for inclined stopes, while eq. (1) 393 was developed for vertical stopes. Their combined use may thus be questioned, as these are 394 based on different assumptions and conditions. Nonetheless, as is often the case with other 395 types of empirical formulations used in geotechnical engineering (such as Jaky's equation for $396 K_{0}$ ), it is deemed reasonable to introduce the value of $K$ given by eq. (6) into eq. (1) to obtain 397 a preliminary estimate of the stresses along the CL of inclined stopes. 


\section{Conclusion}

400 This study presents the results of a numerical investigation conducted with a finite element 401 code to evaluate the effect of stope geometry and backfill properties on the lateral earth 402 pressure coefficient $K\left(=\sigma_{\mathrm{h}} / \sigma_{\mathrm{v}}\right)$ within backfilled stopes. The simulations results indicate that the value of coefficient $K$ along the CL of vertical backfilled stopes can be close to Rankine's

404 active coefficient $K_{\mathrm{a}}$, except near the fill surface. This suggests that the backfill along the CL may be approaching an active state in vertical stopes. As the rock walls do not move significantly, the simulations results also suggest that the backfill state cannot be solely associated with the displacement of these walls. A yielding state, leading to Rankine's active condition, appears to be induced in some parts of the stope due to the natural response of the very soft backfill, which can generate increased (and non-uniform) deviatoric stresses that tends to mobilize the yield strength following filling and settlements. This tendency applies to vertical and inclined stopes. In the latter case however, it has been observed that it is the ratio of the principal stresses $K_{\mathrm{ps}}=\sigma_{3} / \sigma_{1}$ (in 2D) that seems to be approaching Rankine's active coefficient $K_{\mathrm{a}}$ along the inclined CL of the stope. In addition, an empirical equation is proposed for estimating the earth pressure coefficient $K=K_{\alpha}=\sigma_{\mathrm{h}} / \sigma_{\mathrm{v}}$ along the CL of inclined stopes backfilled with a cohesionless backfill.

\section{Acknowledgment}

The authors acknowledge the financial support of the Natural Sciences and Engineering Research Council of Canada (NSERC 402318), the Institut de recherche Robert-Sauvé en santé et en sécurité du travail (IRSST 2013-0029), Fonds de recherche du Québec — Nature et technologies (FRQNT 2014-MI-183747, 2015-MI-191676), and the industrial partners of the Research Institute on Mines and the Environment (RIME UQAT-Polytechnique; 
423 http://rime-irme.ca). Particular thanks are also expressed to the Editor, Associate Editor and 424 anonymous reviewers for their constructive comments.

425

426

427

428

429

430

431

432

433

434

435

436

437

438

439

440

441

442

443

444

445

446

447

448

\section{References}

Al-Hussaini, M., and Townsend, F. 1975. Stress deformation of sand under $\mathrm{K}_{0}$ conditions. In Proceedings 5th Panamerican Conference on Soil Mechanics and Foundation Engineering. Vol. 1, pp. 129-136.

Aubertin, M., Li L., Arnoldi, S., Belem, T., Bussière, B., Benzaazoua, M., and Simon, R. 2003. Interaction between backfill and rock mass in narrow stopes. In Proceedings, Soil and rock America 2003. Edited by P. J. Culligan, H. H. Einstein, and A. J. Whittle. Verlag Glückauf Essen (VGE), Essen, Germany. Vol. 1, pp. 1157-1164.

Aysen, A. 2005. Soil mechanics: Basic concepts and engineering applications, Taylor \& Francis, New York.

Benzaazoua, M., Bussière, B., Demers, I., Aubertin, M., Fried, É., and Blier, A. 2008. Integrated mine tailings management by combining environmental desulphurization and cemented paste backfill: Application to mine Doyon, Quebec, Canada. Minerals Eng., 21: 330-340.

Blight, G. 2006. Assessing loads on silos and other bulk storage structures: Research applied to practice. Taylor \& Francis, Rotterdam, Netherlands.

Blight, G. 2010. Geotechnical engineering for mine waste storage facilities. CRC Press, Netherlands.

Bowles, J.E. 1992. Engineering properties of soils and their measurement, $4^{\text {th }}$ Edition. McGraw-Hill.

Bussière, B. 2007. Colloquium 2004: Hydro-geotechnical properties of hard rock tailings from metal mines and emerging geo-environmental disposal approaches. Canadian Geotechnical Journal, 44(9): 1019-1052.

Caceres, C. 2005. Effect of delayed backfill on open stope mining methods. M.S. thesis, University of British Columbia, Vancouver, B.C.

CGS 2006. Canadian foundation engineering manual, 4th Edition. Canadian Geotechnical Society. 
449

450

451

452

453

454

455

456

457

458

459

460

461

462

463

464

465

466

467

468

469

470

471

472

473

474

475

Coulomb, C.A. 1776. Essai sur une application des règles de maximis \& minimis à quelques problèmes de statique, relatifs à l'architecture. Mémoires de mathématique \& de physique présentés à l'Académie Royale des Sciences par divers savans \& lûs dans ses assemblées, 7: 343-382.

Darling, P. (editor) 2011. SME Mining Engineering Handbook, Third Edition. SME, Littleton.

Das, B.M. 2010. Principles of geotechnical engineering, 7th Edition. Cengage Learning.

El Mkadmi, N., Aubertin, M., and Li, L. 2014. Effect of drainage and sequential filling on the behavior of backfill in mine stopes. Canadian Geotechnical Journal, 51(1): 1-15.

Fahey, M., Helinski, M., and Fourie, A. 2009. Some aspects of the mechanics of arching in backfilled stopes. Canadian Geotechnical Journal, 46(11): 1322-1336.

Falaknaz, N. 2014. Analysis of geomechanical behavior of two adjacent backfilled stopes based on two and three dimensional numerical simulations. Ph.D thesis, École Polytechnique de Montréal, Canada.

Falaknaz, N., Aubertin, M., and Li, L. 2015a. Numerical analyses of the stress distribution in two neighbouring backfilled stopes. International Journal of Geomechanics, 15(6): 04015005.

Falaknaz, N., Aubertin, M., and Li, L. 2015b. A numerical investigation of the geomechanical response of adjacent backfilled stopes. Canadian Geotechnical Journal, 52: 1507-1525.

Fall, M., and Nasir, O. 2010. Mechanical behaviour of the interface between cemented tailings backfill and retaining structures under shear loads. Geotechnical and Geological Engineering, 28(6): 779790.

GEO-SLOPE 2010. Stress-Deformation Modeling with SIGMA/W 2007. An Engineering Methodology, $4^{\text {th }}$ Edition, GEO-SLOPE International Ltd, Canada.

Handy, R.L., and Spangler, M. 2007. Geotechnical engineering: soil and foundation principles and practice. McGraw Hill Professional.

Hambley, D.F. 2011. Backfill mining. In SME mining engineering handbook. Edited by P. Darling. SME, Littleton. Vol 1, pp. 1375-1384.

Hassani, F., and Archibald, J. 1998. Mine backfill (CD-ROM). Canadian Institute of Mining, Metallurgy and Petroleum, Montreal. 
Holtz, R.D., Kovacs, W.D., and Sheahan, T.C. 2011. An Introduction to Geotechnical Engineering. Pearson Education, Limited.

Hughes, P., Pakalnis, R., Hitch, M., and Corey, G. 2010. Composite paste barricade performance at Goldcorp Inc. Red Lake Mine, Ontario, Canada. International Journal of Mining, Reclamation and Environment, 24(2): 138-150.

Jahanbakhshzadeh, A. 2016. Analyse du comportement géomécanique des remblais miniers dans des excavations souterraines inclinées. Ph.D. thesis, École Polytechnique de Montréal, Montréal, QC.

Jaky, J. 1944. The coefficient of earth pressure at rest. Journal of the Society of Hungarian Architects and Engineers, 78(22): 355-358.

Janssen, H.A. 1895. Versuche über getreidedruck in gilozellen. Verein Deutscher Ingenieure, 39: 1045-1049.

Koupouli, N.J.F., Belem, T., Rivard, P., and Effenguet, H. 2016. Direct shear tests on cemented paste backfill-rock wall and cemented paste backfill-backfill interfaces. Journal of Rock Mechanics and Geotechnical Engineering (available online).

Ladd, C.C., Foote, R., Ishihara, K., Schlosser, F., and Poulos, H.G. 1977. Stress deformation and strength characteristics, state of the art report. In Proceedings of the Ninth International Conference on Soil Mechanics and Foundation Engineering. Vol. 2, pp. 421-494.

Lambe, T.W., and Whitman, R.V. 1979. Soil mechanics. John Wiley \& Sons.

Li, L., and Aubertin, M. 2008. An improved analytical solution to estimate the stress state in subvertical backfilled stopes. Canadian Geotechnical Journal, 45(10): 1487-1496.

Li, L., and Aubertin, M. 2009a. Influence of water pressure on the stress state in stopes with cohesionless backfill. Geotechnical and Geological Engineering, 27(1): 1-11.

Li, L., and Aubertin, M. 2009b. A three-dimensional analysis of the total and effective stresses in submerged backfilled stopes. Geotechnical and Geological Engineering, 27(4): 559-569.

Li, L., and Aubertin, M. 2009c. Numerical investigation of the stress state in inclined backfilled stopes. International Journal of Geomechanics, 9(2): 52-62.

Li, L., and Aubertin, M. 2010. An analytical solution for the nonlinear distribution of effective and total stresses in vertical backfilled stopes. Geomechanics and Geoengineering, 5(4): 237-245. 
504

505

506

507

508

509

510

511

512

513

514

515

516

517

518

519

520

521

522

523

524

525

526

527

528

529

530

531

Li, L., and Aubertin, M. 2015. Numerical analysis of the stress distribution in backfilled trenches with inclined walls. Indian Geotechnical Journal, 45(3): 278-290.

Li, L., Aubertin, M., Simon, R., Bussière, B., and Belem, T. 2003. Modeling arching effects in narrow backfilled stopes with FLAC. In In FLAC and Numerical Modeling in Geomechanics - 2003.

Edited by R. Brummer, P. Andrieux, C. Detournay, and R. Hart. A.A. Balkema, Rotterdam, The Netherlands. pp. 211-219.

Li, L., Aubertin, M., and Belem, T. 2005. Formulation of a three dimensional analytical solution to evaluate stresses in backfilled vertical narrow openings. Canadian Geotechnical Journal, 42(6): 1705-1717.

Li, L., Dubé, J.S., and Zangeneh-Madar, Z. 2012. Estimation of total and effective stresses in trenches with inclined walls. International Journal of Geotechnical Engineering, 6(4), 525-538.

Li, L., Dubé, J.S., and Aubertin, M. 2013. An extension of Marston's solution for the stresses in backfilled trenches with inclined walls. Geotechnical and Geological Engineering, 31(4): 10271039.

Liu, G.S., Li, L., Yang, X.C., Guo, L.J. 2016a. A numerical analysis of the stress distribution in backfilled stopes considering interfaces between backfill and rock walls. ASCE-International Journal of Geomechanics 06016014-1-06016014-9 (available online).

Liu, G.S., Li, L., Yang, X.C., Guo, L.J. 2016b. A numerical analysis of the stress distribution in backfilled stopes considering non-planar interfaces between backfill and rock walls. International Journal of Geotechnical Engineering, 10(3): 271-282.

Marston, A. 1930. The theory of external loads on closed conduits in the light of the latest experiments. Bulletin No. 96, Iowa, Engineering Experiment Station, Ames, Iowa.

McCarthy, D.F. 1988. Essentials of soil mechanics and foundations: Basic geotechnics. Prentice Hall, Englewood Cliffs, N.J.

McCarthy, D.F. 2007. Essentials of soil mechanics and foundations: Basic geotechnics, $7^{\text {th }}$ Edition. Prentice Hall Books.

Mesri, G., and Hayat, T. 1993. The coefficient of earth pressure at rest. Canadian Geotechnical Journal, 30(4): 647-666. 
532 Michalowski, R.L. 2005. Coefficient of earth pressure at rest. Journal of Geotechnical and 533 Geoenvironmental Engineering, 131(11): 1429-1433.

534 Pirapakaran, K., and Sivakugan, N. 2007a. Arching within hydraulic fill stopes. Geotechnical and 535 Geological Engineering, 25(1): 25-35.

536 Pirapakaran, K., and Sivakugan, N. 2007b. A laboratory model to study arching within a hydraulic fill 537 stope. Geotechnical Testing Journal, ASTM, 30(6): 496-503.

538 Rankine, W.J.M. 1857. On the stability of loose earth. Philosophical Transactions of the Royal Society 539 of London, London, 147: 9-27.

540 Singh, S., Sivakugan, N., and Shukla, S.K. 2010. Can soil arching be insensitive to $\phi$ ? International $541 \quad$ Journal of Geomechanics, 10(3): 124-128.

542 Singh, S., Shukla, S.K., and Sivakugan, N. 2011. Arching in inclined and vertical mine stopes. 543 Geotechnical and Geological Engineering, 29(5): 685-693.

544 Sobhi, M.A. 2014. Analyse numérique visant l'évaluation du coefficient de pression des terres et des 545 contraintes dans des chantiers remblayés au-dessus d'un pilier-dalle. M.Sc.A. thesis, École $546 \quad$ Polytechnique de Montréal.

547 Sobhi, M.A., Li, L., and Aubertin, M. 2014. Numerical investigation of the lateral earth pressure 548 coefficient along the VCL of vertical backfilled stopes. In GeoRegina 2014. Canadian Geotechnical 549 Society.

550 Take, W., and Valsangkar, A. 2001. Earth pressures on unyielding retaining walls of narrow backfill 551 width. Canadian Geotechnical Journal, 38(6): 1220-1230.

552 Terzaghi, K., Peck, R.B., and Mesri, G. 1996. Soil mechanics in engineering practice. John Wiley \& $553 \quad$ Sons, New York.

554 Thompson, B., Bawden, W., and Grabinsky, M. 2012. In situ measurements of cemented paste backfill 555 at the Cayeli Mine. Canadian Geotechnical Journal, 49(7): 755-772.

556 Ting, C.H., Shukla, S.K., and Sivakugan, N. 2011. Arching in soils applied to inclined mine stopes. 557 International Journal of Geomechanics, 11(1): 29-35.

558 Ting, C.H., Sivakugan, N., and Shukla, S.K. 2012. Laboratory simulation of the stresses within 559 inclined stopes. Geotechnical Testing Journal, ASTM, 35(2): 280-294. 
560 Ting, C.H., Sivakugan, N., Read, W., and Shukla, S.K. 2014. Analytical Expression for Vertical Stress

561 within an Inclined Mine Stope with Non-parallel Walls. Geotechnical and Geological Engineering, $562 \quad 32(2): 577-586$.

563 Van Horn, D. 1964. A study of loads on underground structures. In Proceedings of the Symposium on 564 Soil-Structure Interaction, 8-11 June 1964. University of Arizona, Tucson, Ariz., pp. $256-282$.

565 Winch, C. 1999. Geotechnical characteristics and stability of paste backfill at BHP Cannington mine. 566 B. E. Hons Thesis, James Cook University, Townsville, Australia.

567 


\section{List of tables}

570 Table 1. Characteristics of the different simulations (with $\gamma=18 \mathrm{kN} / \mathrm{m}^{3}, E=300 \mathrm{MPa}, \mu=0.2$

571 and $\psi=0^{\circ}$ for the backfill).

572 
List of figures

575 Fig. 1. Experimentally measured average vertical stresses reported by Pirapakaran and Sivakugan (2007b) for (a) a $600 \mathrm{~mm}$ high and $100 \mathrm{~mm}$ wide square stope, and (b) a $900 \mathrm{~mm}$ high and

577

578

579

580

581

582

583

584

585

586

587

588

589

590

591

592

593

594

595

596

597

598

$150 \mathrm{~mm}$ wide square stope; the stresses measured in the laboratory tests are compared with those obtained from the 3D analytical solution of Li et al. (2005) using Rankine's active $\left(K_{\mathrm{a}}\right)$ and Jaky's at-rest $\left(K_{0}\right)$ earth pressure coefficients. Material properties (taken form Pirapakaran and Sivakugan 2007b): $\gamma=17.53 \mathrm{kN} / \mathrm{m}^{3}, \phi=35^{\circ}, \delta=0.83 \phi$.

Fig. 2. Schematic view of (a) a typical backfilled stope model and (b) the numerical model built with SIGMA/W.

Fig. 3. (a) Distribution of the stresses along the CL of the reference case configuration. (b) Isocontours of the horizontal stress $\sigma_{\mathrm{h}}$ in the stope (increments of $10 \mathrm{kPa}$ ). (c) Iso-contours of the vertical stress $\sigma_{\mathrm{v}}$ in the stope (increments of $50 \mathrm{kPa}$ ). The left side of (b) and (c) corresponds to the plane of symmetry for the vertical stope (see details in Table 1, Case 0).

Fig. 4. Variation of earth pressure coefficient $K$ along the $C L$ of the backfilled stope for the reference case simulated with Sigma (dots); the values of $K$ obtained from eqs. (4) to (5) are also shown in the figure (see Table 1, Case 0 ).

Fig. 5. Variation of lateral earth pressure coefficient along the vertical CL of the stope for various widths $B$; the figure shows the values obtained from the numerical simulations (dots) and from eqs. (4) to (5) (Case 1, Table 1).

Fig. 6. Variation of lateral earth pressure coefficient along the vertical CL of the stope for various inclination angles $\alpha$; the figure shows the values obtained from the numerical simulations (dots) and from eqs. (4) to (5) (Case 2 in Table 1).

Fig. 7. Variation of the ratio $K_{\mathrm{ps}}=\left(\sigma_{3} / \sigma_{1}\right)$ along the $\mathrm{CL}$ of backfilled stopes with various inclination angles $\alpha$; the figure shows the values obtained from the numerical simulations (dots) and from eqs. (4) to (5) (Case 2, Table 1). 
599 Fig. 8. Variation of lateral earth pressure coefficient along the vertical CL of the stope for various

600

601

602

603

604

605

606 internal friction angles $\phi$; the figure shows the values obtained from the numerical simulations (dots) and from Rankine's active coefficient; more details are given in Table 1, Case 3.

Fig. 9. Comparison between the variation of lateral earth pressure coefficient for various stope inclination angles and their corresponding $K\left(\phi=30^{\circ}\right.$; Case 2, Table 1).

Fig. 10. Yield state of the backfill in (a) a vertical stope and (b) an inclined stope. 
Table 1. Characteristics of the different simulations (with $\gamma=18 \mathrm{kN} / \mathrm{m}^{3}, E=300 \mathrm{MPa}, \mu=0.2$ and $\psi$ $=0^{\circ}$ for the backfill)

\begin{tabular}{|c|c|c|c|c|}
\hline \multirow{2}{*}{ Cases } & \multirow{2}{*}{ Figures } & \multicolumn{2}{|c|}{ Stope geometry } & Backfill properties \\
\cline { 3 - 5 } & & $B(\mathrm{~m})$ & $\alpha\left(^{\circ}\right)$ & $\phi\left(^{\circ}\right)$ \\
\hline Case 0 & 3,4 & 6 & 90 & 30 \\
\hline Case 1 & 5 & VAR $^{1}$ & 90 & 30 \\
\hline Case 2 & $6,7,9$ & 6 & VAR & 30 \\
\hline Case 3 & 8 & 6 & 90 & VAR \\
\hline
\end{tabular}

${ }^{\mathrm{I}} \mathrm{VAR}=$ Variable 


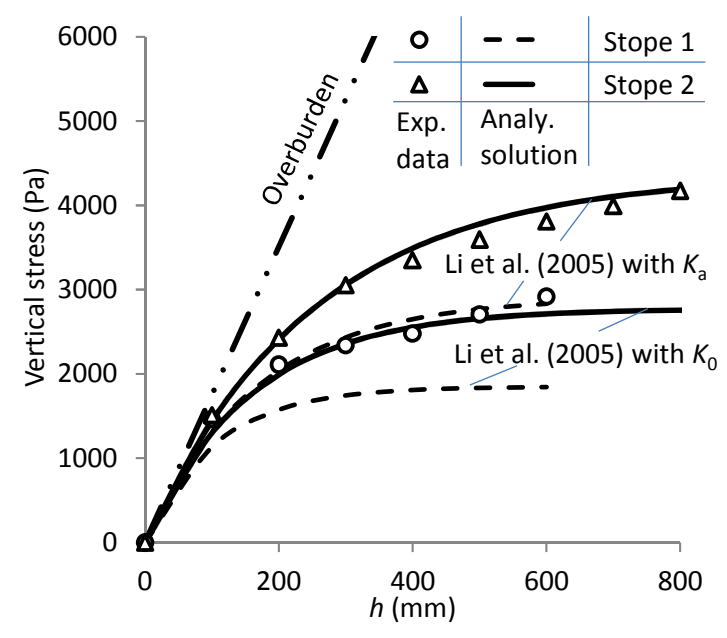

Fig. 1. Experimentally measured average vertical stresses reported by Pirapakaran and Sivakugan (2007b) for a $600 \mathrm{~mm}$ high and $100 \mathrm{~mm}$ wide square stope (Stope 1), and a $900 \mathrm{~mm}$ high and $150 \mathrm{~mm}$ wide square stope (Stope 2); the stresses measured in the laboratory tests are compared with those obtained from the 3D analytical solution of Li et al. (2005) using Rankine's active $\left(K_{\mathrm{a}}\right)$ and Jaky's atrest $\left(K_{0}\right)$ earth pressure coefficients. Material properties (taken form Pirapakaran and Sivakugan 2007b): $\gamma=17.53 \mathrm{kN} / \mathrm{m}^{3}, \phi=35^{\circ}, \delta=0.83 \phi$. 
(a)

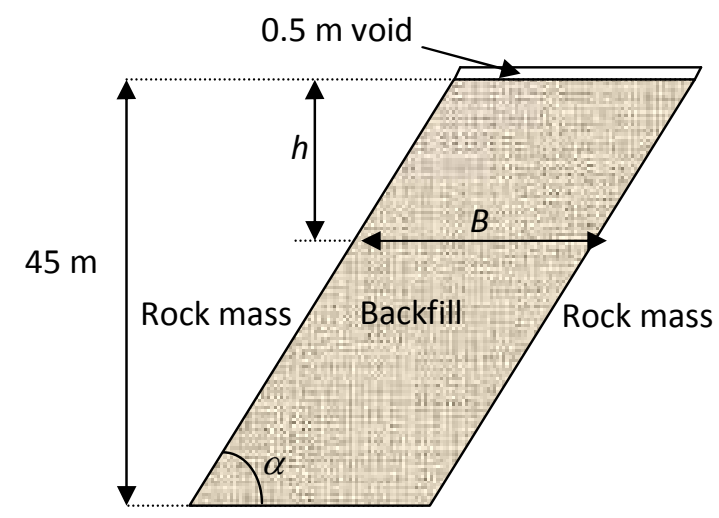

(b)

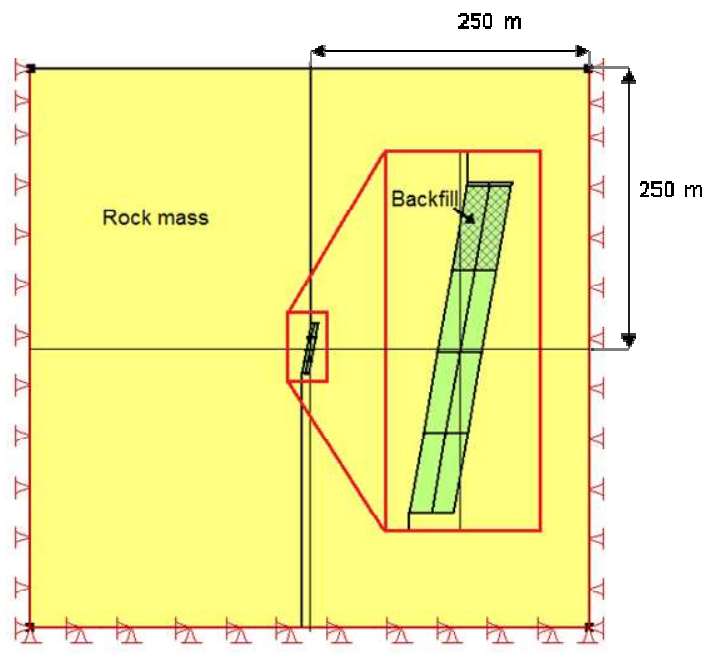

Fig. 2. Schematic view of (a) a typical backfilled stope model and (b) the numerical model built with SIGMA/W. 


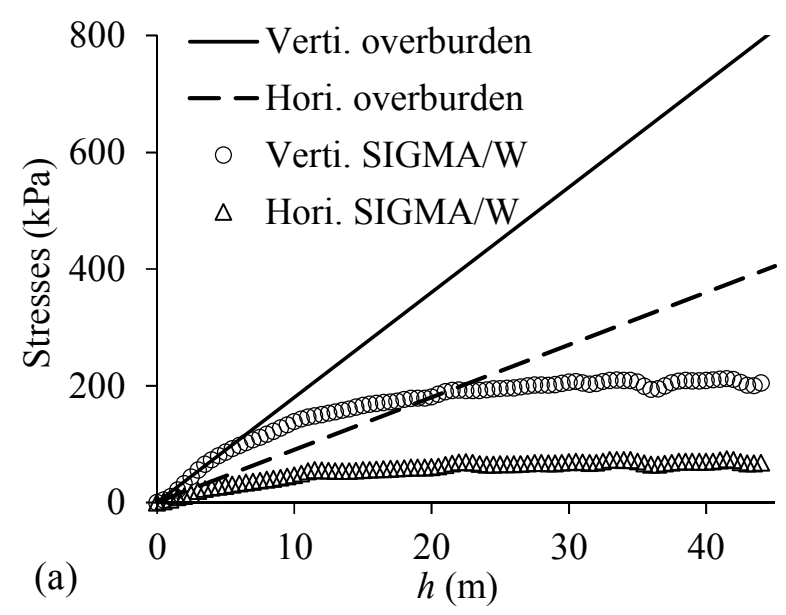

(b)

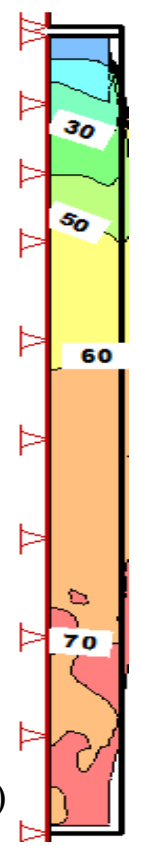

(c)

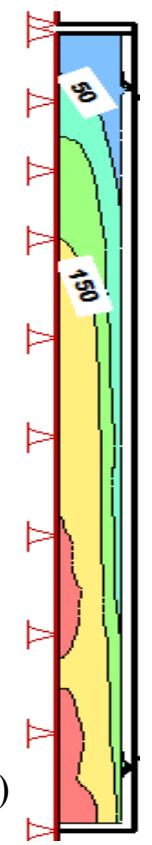

Fig. 3. (a) Distribution of the stresses along the CL of the reference case configuration. (b) Isocontours of the horizontal stress $\sigma_{\mathrm{h}}$ in the stope (increments of $10 \mathrm{kPa}$ ). (c) Iso-contours of the vertical stress $\sigma_{\mathrm{v}}$ in the stope (increments of $50 \mathrm{kPa}$ ). The left side of (b) and (c) corresponds to the plane of symmetry for the vertical stope (see details in Table 1, Case 0).

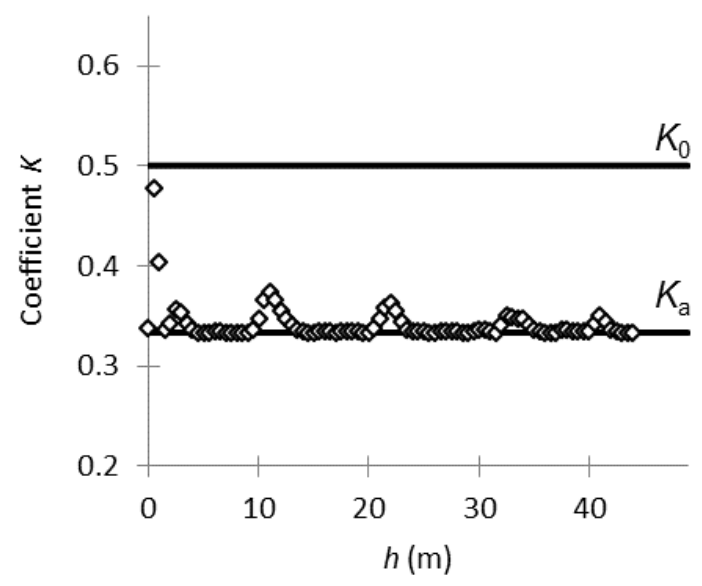

Fig. 4. Variation of earth pressure coefficient $K$ along the CL of the backfilled stope for the reference case simulated with SIGMA/W (dots); the values of $K$ obtained from eqs. (4) to (5) are also shown in the figure (see Table 1, Case 0). 


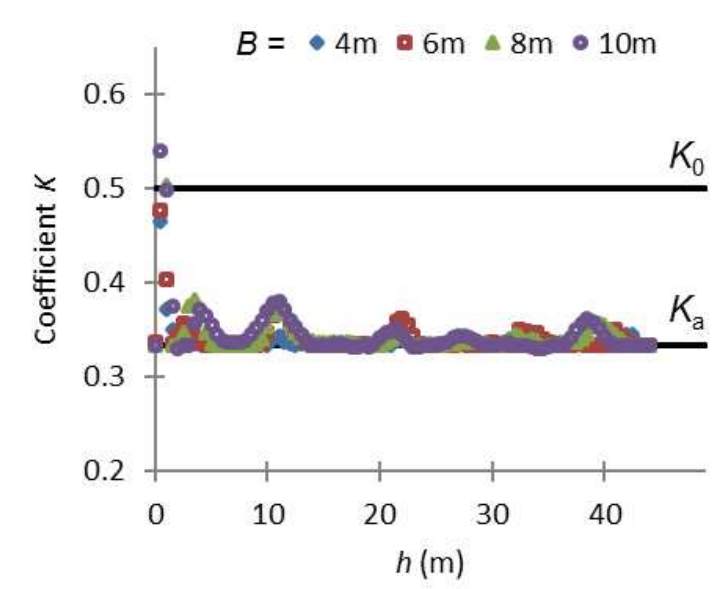

Fig. 5. Variation of lateral earth pressure coefficient along the vertical CL of the stope for various widths $B$; the figure shows the values obtained from the numerical simulations (dots) and from eqs. (4) to (5) (Case 1, Table 1).

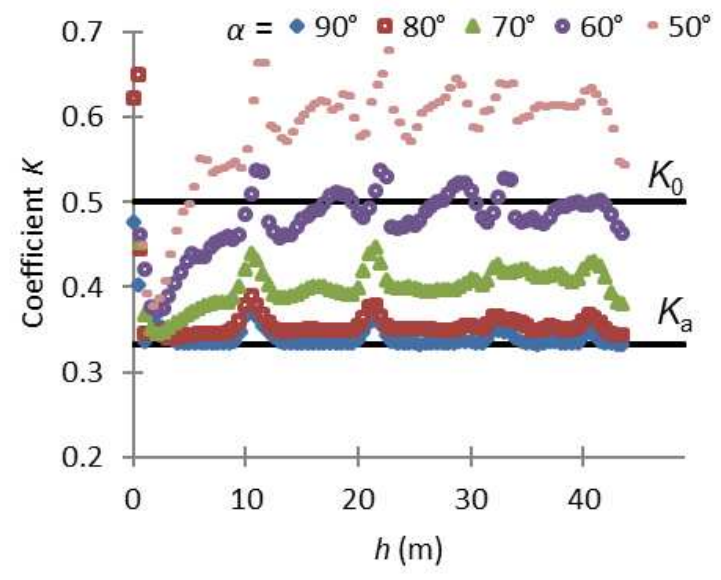

Fig. 6. Variation of lateral earth pressure coefficient along the vertical CL of the stope for various inclination angles $\alpha$; the figure shows the values obtained from the numerical simulations

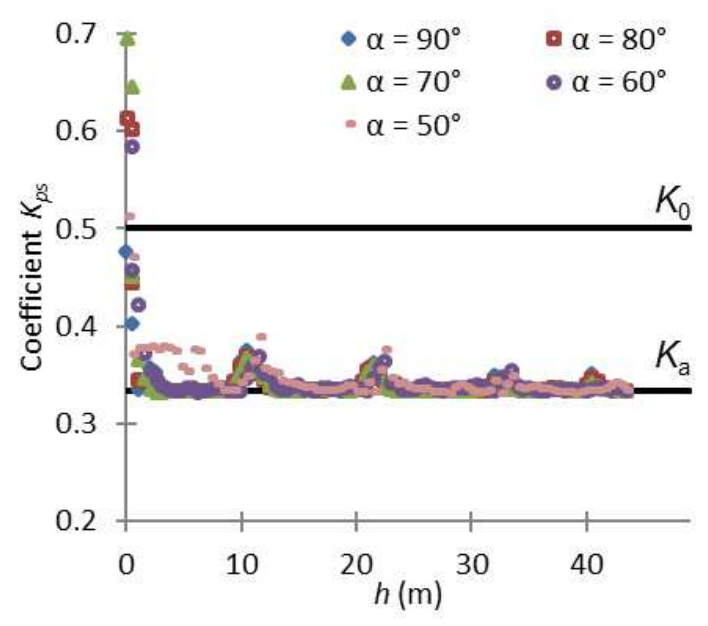

Fig. 7. Variation of the ratio $K_{p s}=\left(\sigma_{3} / \sigma_{1}\right)$ along the $\mathrm{CL}$ of backfilled stopes with various inclination angles $\alpha$; the figure shows the values obtained from the numerical simulations (dots) and from eqs. (4) to (5) (Case 2, Table 1). 


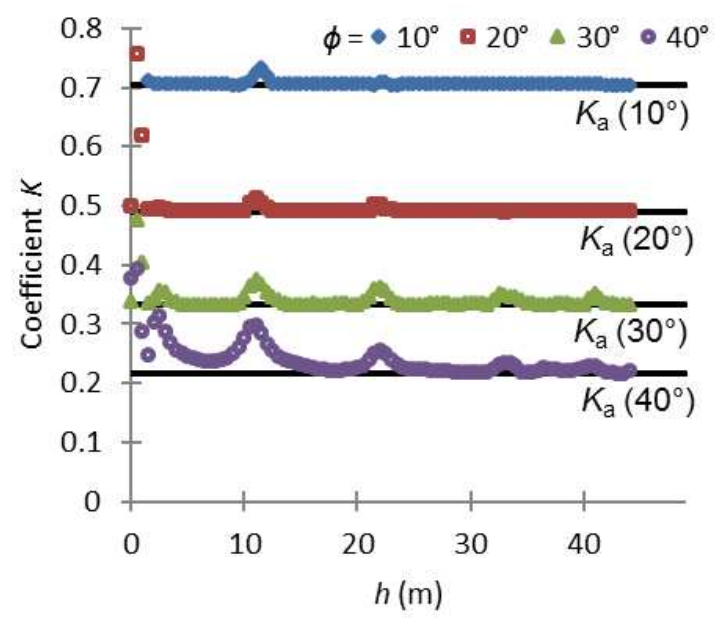

Fig. 8. Variation of lateral earth pressure coefficient along the vertical $C L$ of the stope for various internal friction angles $\phi$; the figure shows the values obtained from the numerical simulations (dots) and from Rankine's active coefficient; more details are given in Table 1, Case 3.

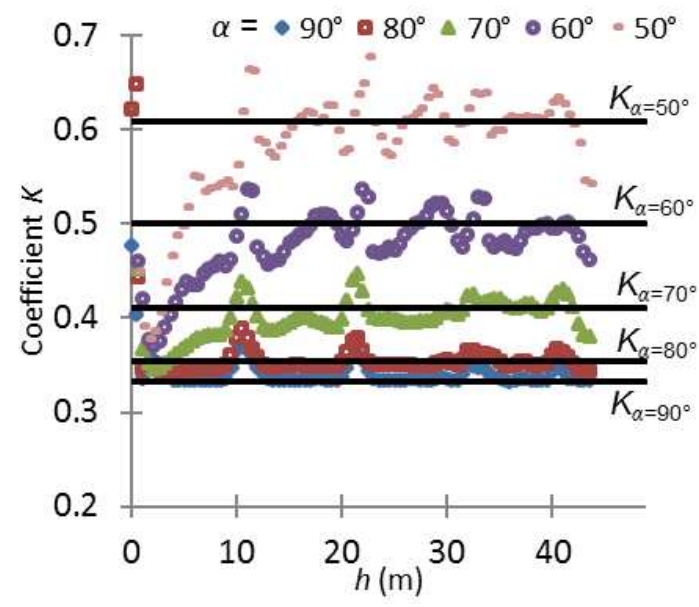

Fig. 9. Comparison between the variation of lateral earth pressure coefficient for various stope inclination angles and their corresponding $K\left(\phi=30^{\circ}\right.$; Case 2, Table 1). 
(a)

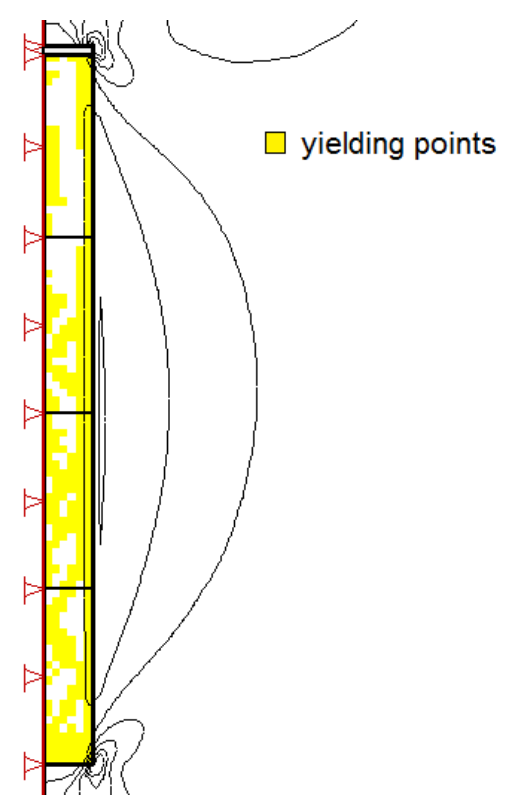

(b)

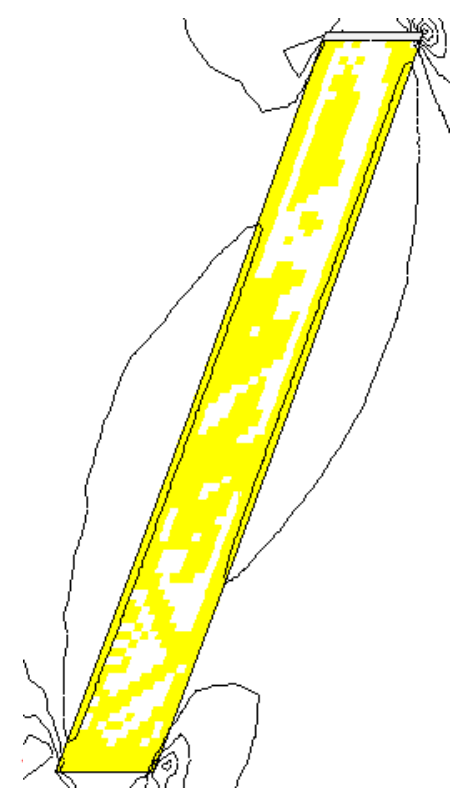

Fig. 10. Yield state of the backfill in (a) a vertical stope and (b) an inclined stope. 